\title{
In the Search for Novel Wine Yeast with Deacidification Activity
}

\section{Alina Kunicka-Styczyńska*}

Institute of Fermentation Technology and Microbiology, Technical University of Lodz, Poland

Although Poland is not widely recognized as a wine-producing country, grapevine cultivation and winemaking dates back to the beginning of Christianity in this country in the $10^{\text {th }}$ century. Over the centuries, vineyards and wineries have spread and are now located mainly in Zielona Góra, Małopolska, Sandomierz and Podkarpacie [1]. Grape cultivation in Poland has been intensively developing in the last years, with a total cultivated area of about 2000 ha with more than 2000 vineyards. According to the Council of the European Union, Poland has been classified as a wine-growing region A (the coldest), similarly as Germany, Austria, Slovakia, and the Czech Republic, and Polish grape wines have been officially admitted to the EU market [2]. One of the main problems of cold-climate countries is an excess of grape acidity. However in Poland the grapes for cultivation are carefully selected, their acidity varies substantially from season to season. Moreover, fruit winery is well developed in Poland. In the light of Polish law, according to the Wine Making Act [3], branded fruit wine may also be produced from fruits other than grapes. Fruit wines have undoubtedly substantial potential for the Polish wine-making industry, with an output of $690,000 \mathrm{hL}$ in the first three quarters of 2011. Poland is one of the leading producers of apples in the EU (24\% of European production) [4], so apple musts are used in cider production and serve as a component of fruit wines. Moreover, Polish apple and cherry wines have been well received in Italy, Germany and Sweden [5].

Grape musts from cold regions and most fruit musts reveal excess acidity. Too high content of organic acids unfavorably affects wine yeasts [6], and the obtained wines are characterized by an improper balance between sugar, acid, and aroma components [7-9]. One of the strategies for solving this problem is biological deacidification by wine yeasts with an extended ability to degrade L-malic acid. In terms of organic acid content in grapes, malic acid is second only to tartaric acid; together they account for up to $90 \%$ of all the acids present [10]. In terms of other fruits used in the Polish wine-making industry, malic acid content reaches $94 \%-98 \%$ of total acids present in apples and cherries [11]. The demalication activity of Saccharomyces varies substantially $(0 \%-48 \%)$ and is strain dependent $[7,12]$. The rather low malate decomposition is explained by the absence of an active L-malate transport system, the low substrate affinity of the malic enzyme, and the mitochondrial location of two malic isoenzymes $[8,13,14]$. Under fermentation, the enzyme is subjected to the regulatory effect of fermentative glucose metabolism due to mitochondria dysfunction and deterioration $[8,15]$. The metabolic impact of yeast on the wine character is undisputable and the right selection of stable yeast strains determines both the performance of the fermentation process and wine quality [16]. To meet winemakers' demands, there is a constant search for selection and development of new wine strains addressed exactly for highly acidic musts. Among waste range of Polish, Italian and Hungarian commercial and collection strains six wine races expressing high demalication activity were selected and characterized [17]. To accelerate the feature of L-malic acid fermentation, the wine yeasts Saccharomyces cerevisiae and Saccharomyces bayanus var. uvarum were crossed and natural hybrids obtained. The hybrids originating from commercially used wine yeasts are of the high technological value. The natural hybridization technique allows the yeast to preserve their fermentative features and enhance deacidification ability. The hybrids can decompose up to $77 \%$ of malic acid present in musts [18]. Both the wild yeasts and their hybrids can be successfully used in acidic grape and fruit musts fermentation. Surprisingly, the only concern in fruit winery is too low general acidity in case of malic acid predominance in the pool of organic acids. This problem can be overcome by different musts blending. Another approach is to improve L-malic acid decomposition in wine yeasts on a molecular level. The malate permease (mae1) encoding genes from yeast Schizosaccharomyces pombe and malolactic (mleA) genes from bacteria Oenococcus oeni were cloned and coexpressed in $S$. cerevisiae strains $[14,19,20]$. The $S$. pombe malate transporter (mae1) and malic enzyme (mae2) genes were introduced into S. bayanus [21]. The co-expression of the Candida utilis malic enzyme gene (CME1) and $S$. pombe malate transporter gene (mae1) in S. cerevisiae resulted in complete malate degradation [22]. But only the work of Husnik et al. [20] was accomplished by the construction of genetically engineered stable commercial wine $S$. cerevisiae yeast bearing the mael and mleA genes. The recombinant after receiving GRAS status (Generally Recognized as Safe) has been commercialized in Moldova and the USA [15]. Some scientists represent much more metabolic approach. The understanding of the regulation and role of malic acid metabolism in Saccharomyces sensu stricto yeast will substantially contribute to the improvement of commercial wine strains. Saccharomyces paradoxus yeast strain isolated from grapes collected in Jazbina (the Zagreb wine region of Croatia) as well as $S$. bayanus and S. cerevisiae Lalvin active dry yeast strains from Lallemand (France) were used in the research on the transcriptional regulation of malic enzyme gene [23].

The use of new strains of wine yeast with the malo-ethanolic profile will eliminate the cellar operations undertaken to adjust the musts acidity. Although genetically engineered yeasts are characterized by the proper efficiency in malate metabolism, they are not always applicable because of the lack of the GRAS status. The hybrids produced by natural hybridization of wine yeast are safe but may be unstable. Their stability, mainly determined by the genetic relationship, can be improved in the process of adaptive evolution. Moreover, many commercial wine yeasts are interspecific hybrids between yeasts of the Saccharomyces sensu stricto complex.

\section{References}

1. Mysliwiec R (2006) Grapevine and vine. PWRiL, Warsaw, Poland.

*Corresponding author: Alina Kunicka-Styczyńska, Institute of Fermentation Technology and Microbiology, Technical University of Lodz, ul. Wólczańska 171/173, 90-924 Łódź, Poland, Tel: + 484263134 76; Fax: + 484263659 76; E-mail: alina.kunicka@p.lodz.pl

Received April 19, 2012; Accepted April 20, 2012; Published April 23, 2012

Citation: Kunicka-Styczyńska A (2012) In the Search for Novel Wine Yeast with Deacidification Activity. Ferment Technol 1:e106. doi:10.4172/21677972.1000 e106

Copyright: (C) 2012 Kunicka-Styczyńska A. This is an open-access article distributed under the terms of the Creative Commons Attribution License, which permits unrestricted use, distribution, and reproduction in any medium, provided the original author and source are credited. 
Citation: Kunicka-Styczyńska A (2012) In the Search for Novel Wine Yeast with Deacidification Activity. Ferment Technol 1:e106. doi:10.4172/2167$7972.1000 \mathrm{e} 106$

Page 2 of 2

2. Council Regulation (EC) (2005) Official Journal of the European Union L.

3. Act of Wine-Making about production and overflow of winery products, trade and organization of market of wine, Dziennik Ustaw.

4. Makosz E (2011) Harvest, needs and profitability of apples, pears, cherries and sweet cherries production. Proceedings of XXXI International Fruit-Growing Seminar.

5. Lazarowicz A (2006) Polish winery - useful but really appreciated food industry branch? Ferm Fruit Vegetable Ind 3: 32-33.

6. Fleet GH, Heard GM (1993) Yeasts-growth during fermentation. In: Fleet GH (ed) Wine Microbiology and Biotechnology, Harwood Academic Publishers, Chur, Switzerland.

7. Pretorius IS, Bauer FF (2002) Meeting the consumer challenge through genetically customized wine-yeast strains. Trends Biotechnol 20: 426-432.

8. Volschenk H, van Vuuren HJ, Viljoen-Bloom M (2003) Malo-ethanolic fermentation in Saccharomyces and Schizosaccharomyces. Curr Genet 43 379-391.

9. Volschenk H, van Vuuren HJJ, Viljoen-Bloom M (2006) Malic acid in wine: origin, function and metabolism during vinification. S Afr J Enol Vitic 27: 123136.

10. Torija MJ, Beltran G, Novo M, Poblet M, Rozès N, et al. (2003) Effect of organic acids and nitrogen source on alcoholic fermentation: study of their buffering capacity. J Agric Food Chem 51: 916-922.

11. Wzorek W, Pogorzelski E (1998) Technology of fruit and grape winery, Sigma NOT, Poland, 17-42.

12. Rodriguez SB, Thornton RJ (1990) Factors influencing the utilisation of L-malate by yeasts. FEMS Microbiol Lett 60: 17-22.

13. Osothsilp C, Subden RE (1986) Isolation and characterization of
Schizosaccharomyces pombe mutants with defective NAD-dependent malic enzyme. Can J Microbiol 32: 481-486

14. Volschenk H, Viljoen M, Grobler J, Petzold B, Bauer F, et al. (1997) Engineering pathways for malate degradation in Saccharomyces cerevisiae. Nat Biotechno 15: $253-257$

15. Saayman M, Viljoen-Bloom M (2006) The biochemistry of malic acid metabolism by wine yeasts - a review. S Afr J Enol Vitic 27: 113-122

16. Fleet GH (2008) Wine yeasts for the future. FEMS Yeast Res 8: 979-995.

17. Kunicka-Styczynska A, Rajkowska K (2012) Phenotypic and genotypic diversity of wine yeasts used for acidic musts. World J Microbiol Biotechnol.

18. Kunicka-Styczy $\AA$ „ska A, Rajkowska K (2011) Physiological and genetic stability of hybrids of industrial wine yeasts Saccharomyces sensu stricto complex. J Appl Microbiol 110: 1538-1549.

19. Volschenk H, Viljoen M, Grobler J, Bauer F, Lonvaud-Funel A, et al. (1997) Malolactic fermentation in grape musts by a genetically engineered strain of Saccharomyces cerevisiae. Am J Enol Vitic 48: 193-196.

20. Husnik JI, Volschenk H, Bauer J, Colavizza D, Luo Z, et al. (2006) Metabolic engineering of malolactic wine yeast. Metab Eng 8: 315-323.

21. Volschenk H, Viljoen-Bloom M, Van Staden J, Husnik J, van Vuuren HJJ (2004) Genetic engineering of an industrial strain of Saccharomyces bayanus for malic acid degradation via an efficient malo-ethanolic pathway. S Afr J Enol Vitic 25: 63-73.

22. Saayman M, van Zyl WH, Viljoen-Bloom M (2006) Cloning, characterisation, and heterologous expression of the Candida utilis malic enzyme gene. Curr Genet 49: 248-258.

23. Redzepovic S, Orlic S, Majdak A, Kozina B, Volschenk H, et al. (2003) Differential malic acid degradation by selected strains of Saccharomyces during alcoholic fermentation. Int J Food Microbiol 83: 49-61. 